\title{
Non-economic Emigration Factors that Might be Pushing Citizens Out of Lithuania
}

\author{
Thomas Andrew Bryer \\ Kaunas University of Technology \\ A. Mickevičiaus 37, LT-44244 Kaunas, Lithuania \\ Rimantas Rauleckas \\ Kaunas University of Technology \\ A. Mickevičiaus 37, LT-44244 Kaunas, Lithuania \\ Vishnu Murealeedharan \\ Kaunas University of Technology \\ A. Mickevičiaus 37, LT-44244 Kaunas, Lithuania \\ Eglė Butkevičienè \\ Kaunas University of Technology \\ A. Mickevičiaus 37, LT-44244 Kaunas, Lithuania \\ Jolanta Vaičiūnienė \\ Kaunas University of Technology \\ A. Mickevičiaus 37, LT-44244 Kaunas, Lithuania \\ Eglė Vaidelytė \\ Kaunas University of Technology \\ A. Mickevičiaus 37, LT-44244 Kaunas, Lithuania \\ Ramunė Miežanskienė \\ Kaunas University of Technology \\ A. Mickevičiaus 37, LT-44244 Kaunas, Lithuania \\ cross $^{\text {ref }}$ http://dx.doi.org/10.5755/j01.ppaa.19.1.25114
}

\begin{abstract}
Based on a systematic and comprehensive review of literature on emigration, we identify potential non-economic push factors that might drive Lithuanian citizens to emigrate. Based on a random sample nationwide survey conducted in spring 2019 with Lithuanian citizens living in Lithuania, two categories have emerged as most critical non-economic drivers to lead to higher intention to emigrate: quality of working life and confidence in the future. Further research can add necessary nuance to understanding these factors while also experimenting with possible policy and project interventions that can reduce intent to emigrate and/or encourage return migration. This research is implemented under the project "The importance of non-economic factors to the emigration of the Lithuanian population", funded by the Research Council of Lithuania under the Programme "Improvement of researchers' qualification by implementing world-class $R \& D$ projects" (Agreement No. 09.3.3-LMT-K-712-01-170).
\end{abstract}

Keywords: emigration, push/pull factors, Lithuania.

Raktažodžiai: emigracija, stūmos-traukos veiksniai, Lietuva. 


\section{Introduction}

Lithuania has experienced population shrinkage since independence from the Soviet Union in 1991; population decline continues today. Though there might be a reduction in the rate of population decline in the year 2019, the decline is predicted to continue for the foreseeable future in the absence of any policy or initiative or set of policies and initiatives across the nation and within individual municipalities, to stem the tide. In order to determine potentially appropriate and effective policies and initiatives to reduce individual decisions to emigrate, it is necessary to understand the factors that push an individual to want to leave, pull them towards another country, or encourage them to remain in their home municipality or country.

There have been four waves or periods that associate with general spikes in emigration from Lithuania. The first, from 1991 to 2003, is the post-independence period, during which Lithuanian citizens were free to leave the country after fifty years of Soviet occupation. The second was set off with accession to the European Union in 2004; the third was marked by the twin occurrences of the global economic recession and entrance to the Schengen Zone beginning in 2007, which provided Lithuanian citizens free movement throughout the European Union, including for work. The largest emigration spike occurred during this period. Last, in 2015, Lithuania abandoned the litas as its currency and entered into the common currency market.

Local, national, and world events shape conditions and quality of life in Lithuania, which might further alter the emigration landscape. For instance, Brexit might lead to a return of some Lithuanians who created a home in the United Kingdom (UK), or it might reduce the flow of Lithuanian citizens to the UK. It is too soon to judge the impact of this on individual and family decisions to leave Lithuania. However, official projections based on Eurostat data suggest that, if nothing changes, the population will continue to decline through, at least 2070 , and net migration will be negative (emigration is greater than immigration) until approximately 2050.

What is evident in a review of historical data, and what makes it an appealing case for developing theory and practice, is Lithuanian society is prone to spikes in emigration when there are economic slumps, ambiguities, and, consequently, opportunities elsewhere, which is not a unique phenomenon. It is thus essential to look beyond the economic patterns to the social, cultural, political, and psychological.

The main aim of the article is focused on push factors that influence the citizens' intentions to emigrate from Lithuania. To provide full theoretical context, non-push factors are also identified, though only push factors are statistically analyzed. This focus allows for specific concentration on factors that are potentially in the great control of the government and non-government agencies in Lithuania. The article considers a broad theoretical framework for individual decisions to emigrate, as well as empirical data analysis, with a focus on push factors. Analysis of data from a 2019 national survey in Lithuania reveals the push factors that are significant in determining individual intentions to emigrate. This research is implemented under the project "The importance of non-economic factors to the emigration of the Lithuanian population", funded by the Research Council of Lithuania under the Programme "Improvement of researchers' qualification by implementing world-class R\&D projects" (Agreement No. 09.3.3-LMT-K-712-01-170).

\section{Theoretical Perspectives on Push and Pull Factors}

Much of the emigration literature flows through a lens of push/pull: factors that push an individual or family out of their home community or country, and factors that pull an individual or family towards a different community or country. For instance, in economic terms, an individual may be pushed out of their home due to low wages and limited opportunities for professional advancements and thus raised quality of life; they may further be pulled towards a different place if they have ambition for a better, or different, life, and there is the perception that a different country offers those opportunities. Added to the push/pull factors are those that we can call counter push/pull factors, or factors that might serve to persuade an individual to remain in their country, despite factors 
pushing away and pulling towards. Figure 1 shows the general relationship portrayed in the literature between push factors, pull factors, county push/pull factors, and a final decision to emigrate.

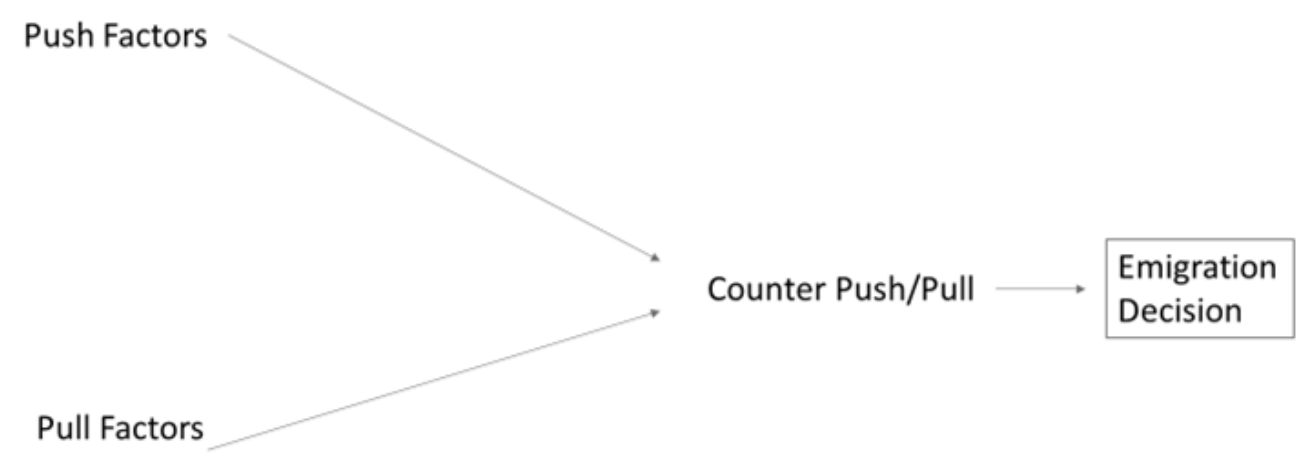

Fig. 1. General Framework for Intention to Emigrate

The literature on push/pull theories and empirical examination of the decision to emigrate has focused on a range of factors or drivers, at the individual, household, regional, and country levels (Castles, 2013). Even in research that has posed the issue as a country-level phenomenon driven by macro-level indicators of well-being, however, can be viewed through an individual lens. For instance, research on crime, poverty, or economic growth, are linked to decisions to emigrate based on the perception of the issues by individuals and how the issues affect them.

When mentioning about the aspect of the "push" and "pull factors" it can be seen that the aspect of pull is associated with the host region with the kind of facilities and infrastructures for the individual advancement whereas the push is associated with the home region especially the barriers for individual development, advancement, the existence which forces the individual to leave the place of origin (Liu et al.,2010). This varies between the regions and among various socio-economic groups as in the low income and deprived groups the aspect of emigration is primarily among the younger male member in search for economic aspects and livelihood to the regional and nearby areas whereas among the economically stable and affluent groups this is for the advancement of the skills and expertise and mainly focuses on international migration (Castaldo et al., 2012).

Among the factors that influence the migrant decisions, apart from the individual decision to emigrate, the individual household also plays a significant role as the household uses the mechanism of emigration as an alternative source for the diversification of the income by the allocation of the additional human workforce to emigrate (Stark et al., 1985). This acts as an insured mechanism for the household to cope with the stress generated by the various interlinked drivers, and if these mechanisms fail to accomplish the desired results, it will lead to the out-migration of the entire household to combat the drivers (Gray et al., 2013). Among the low-income household, it happens especially when the household's income generation ability especially in the wake regional shocks or environmental calamity which compels them to look for alternative means of livelihood in the form of emigration (Stark et al., 1982).

When it comes to the push and pull factors and the drivers of population decline and shrinkage one of the significant drawbacks is the more significant weightage, and significance for the economic drivers than other drivers such as social, political, environmental and demographic as most of these studies were focused on the developed world and its cities which gives paramount significance to the economic drivers (Haase et al., 2013; Hartt, 2018). This is due to the factor that these cities and towns in the developed world were primarily industrial, and business centres and the lack of attractiveness and the closing of the business makes the push factors for emigration and the primary push factor in these scenarios are economic drivers (Ubarevičienè, Van Ham \& Burneika, 2016). However, due to the increasing significance of other drivers and the expansion of research to other industrial and non- 
industrial centres in the developing areas led to the expansion of research to other drivers of emigration such as "environmental" and social drivers which led to the expansion of literature in these fields to have a broader understanding of non-economic drivers of emigration in the "shrinking cities and regions" (Piguet, 2010).

Concerning the push and pull aspects of emigration, it can be noticed that there are significant barriers associated with immigration in national, regional and international migration. One of the significant barriers is the aspect of employability in the host regions, and it depends upon the skills and expertise of the employee and the adaptability to the new environment. Another barrier concerning the employability of the migrant is the aspect of "social networks", and it can be perceived that those individuals and communities with enhanced social networking are able to find the employment in the host places than those who lack social networking and this is mainly facilitated by family networks, relationships and friends (Wan et al., 2018). Another significant barrier is the integration of the migrants in the host societies and communities. When there are significant social networks and diaspora in the host regions, it led to the effective integration of the migrant communities and when they lack these social networks and connections it led to a situation of "alienation" of the migrants even though the economic drivers are fulfilled whereas the social integration and cohesion left out (Bernosky de Flores, C., 2010).

\section{Push Factors to Test in Lithuanian Context}

To establish specific testable factors for a nationwide survey in Lithuania to understand contributors of decisions to emigrate, we conducted a systematic review of the literature on emigration using EBSCOhost online database. We included peer-reviewed journal articles in English and Lithuanian languages published between 2012 and 2018, using 19 unique keywords, plus 18 of those keywords with the addition of the word "Lithuania." In total 24,198 articles were returned through the keyword search. Two coders read the abstracts of each article and further, if necessary, to assess relevance of the article to the research topic. Of the articles returned, 787 were deemed to be relevant, or approximately 3 percent. Irrelevant articles included those that addressed, for example, immigration, immigrant integration, as well as forced migration, each of which is not linked to this research topic. All relevant articles were divided across 5 researchers for reading and further coding of key article findings and components, including factors contributing to emigration, country or countries of focus, specific profession of focus (e.g., medical doctors), academic discipline, methods used, and applied theories.

The keywords used in the search were the following:

- Brain drain

- Causes

- Civic

- Civil Society Determinants

- Education

- Exit Voice Loyalty

- Hirschman

- Identity

- Lithuania

- Motivation

- Psychology

- Repeat

- Reverse

- Rural

- Social Causes

- Social Determinants

- Tracking

- Urban 
Based on our review of the literature, we identified fifteen categories of non-economic factors that have been found to contribute to decisions to emigrate or to remain. These include nine push factor categories, three pull factors, and three counter push/pull factors. Figure 2 shows these categories. Our focus in this article is only on the push factors; these variables are described further.

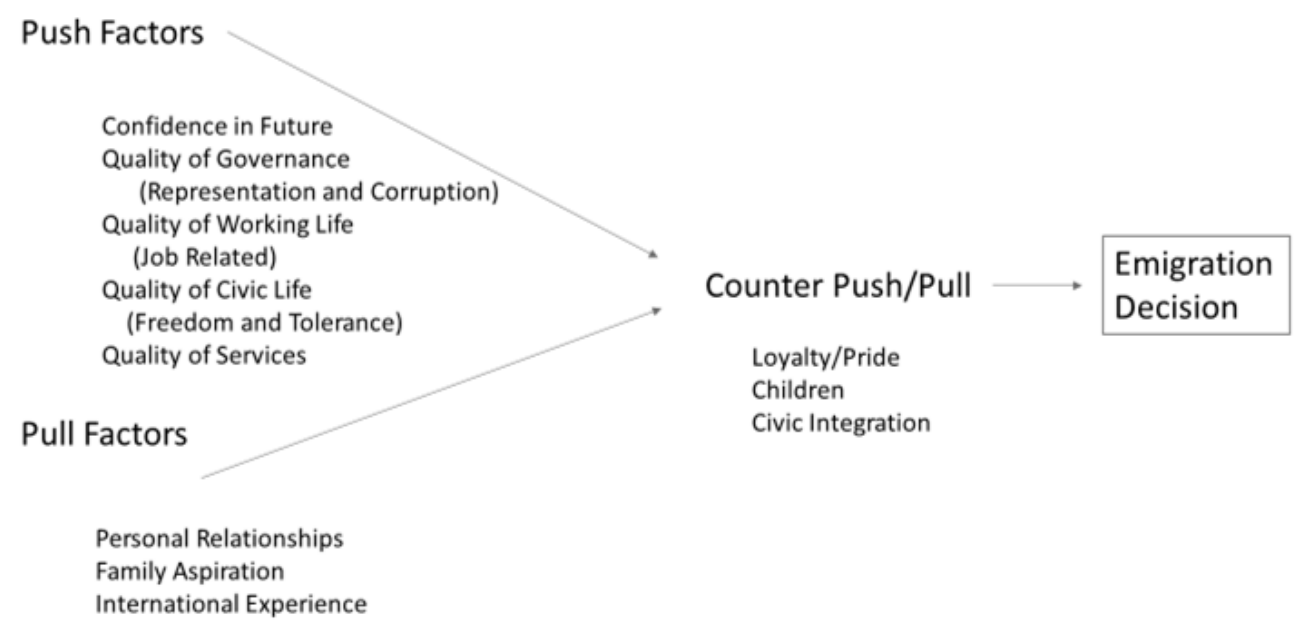

Fig. 2. Categories of Push/Pull/Counter Push-Pull Factors

\section{Non-Economic Push Factors}

Nine categories of variables, as derived from the literature, were identified for testing in a nationwide survey in Lithuania. These are: (1) Quality of Services, including distinct sub-categories of Education, Culture and Sport, Safety and Security, and Health and Social, (2) Quality of Working Life (Job Related), (3) Confidence in the Future, (4) Quality of Society (Freedom and Tolerance), and (5) Quality of Civic Life (Civic and Corruption).

\section{Quality of Services}

There are a number of quality of services issues that have been found as inducements to stay or leave one's country or community, within a country. These include perceptions of the healthcare system, level of taxation, living standards, safety, and cultural opportunities such as found through the arts. These factors go beyond the "traditional" factors that might affect decisions to emigrate, such as wage and social conditions and employment opportunities (Kumpikaite and Zickute 2012). Enhancements in these aspects of quality of life are potentially likely to be found more in more urbanized areas, thus leading to a larger exodus from rural communities (Azderski and Popovska 2015). This, of course, is no certainty, particularly in nations where wages are low relative to costs of living and taxation is high. We see such dynamics in nations struggling with debt, such as Greece (Ifanti et al. 2014), or social unrest, such as in South Africa (Tabor, Milfont and Ward 2015). The constraints placed from above in such places, from national or supra-national level, will potentially further constrain municipal discretion to act against more localized emigration. In all categories of qualities of service, the following hypotheses apply:

Hypothesis 1: The lower perceived quality of services, the more likely an individual will express an intention to emigrate. 


\section{Quality of Working Life (Job Related)}

Some individuals might place more emphasis on the quality of their working life, relative to other quality of life and services factors seen in other parts of the literature (Hercog and Van de Laar 2017). In the literature, we find the suggestion of quality of working life or job-related factors that might be influential in decisions to emigrate. These include job satisfaction, job security, salary level, spouse employment prospects, working conditions, working hours, and prestige of employment of profession within the society.

In speciality fields of employment, particularly those that require years of advanced training and formal university education, quality of working life has been identified as critical. The idea of brain drain is most linked to this dynamic of lost specialized, high-skilled talent. Researchers have seen it in diverse societies, including with physiotherapists in Nigeria (Oyeyemi et al. 2012), Chinese academicians ( $\mathrm{Fu}$ 2014), and Korean nurses (Lee and Moon 2013). We see the patterns more generally with highly skilled and educated individuals in Central and East Europe (Lados 2014; Ailencei, Badea and Dima 2015), as well as with global healthcare professionals and their desire to go to higher-value locations such as North America, the UK, and Australia (Clarke et al. 2017; Zubaran 2012). In this category, we suggest the following hypothesis:

Hypothesis 2: The lower overall satisfaction in one's working life, the more likely an individual will express an intention to emigrate.

\section{Confidence in the Future}

Researchers have shown the significance of factors related to perceived future personal and professional opportunities for advancement, as well as overall confidence in the future to take advantage of such opportunities, particularly if there are risks of significant life challenges. Perceived inequality for a future career or professional advancement was found as an essential factor in a variety of places, including physicians in Pakistan (Sheikh et al. 2012), and across national borders where social and economic inequality correlate with emigration rates (Stolz and Baten 2012) or where there are higher rates of corruption thus potentially creating an unfair field for personal advancement (Cooray and Schneider 2015).

Assuming limited inequality in this regard, training availability in one's home country or municipality, as compared to similar opportunities in another place, contributes to decisions to emigrate. We see this amongst healthcare workers in Ireland (Clarke et al. 2017) and India (WaltonRoberts et al. 2017), nurses in Brazil (Silva et al. 2016), and other speciality health fields in the Pacific Island region (Yamomoto et al. 2012), within the European (Macerollo et al. 2014), and Iraq (AlKhalisi 2013). Additionally, we see the importance of training opportunities amongst medical and other specialized university students, including in places like Ghana (Lassey, Lassey and Boamah 2013), Ethiopia (Deressa and Azazh 2012), Philippines (Castro-Palaganas et al. 2017), and Portugal (Cerdeira et al. 2016). In this category, the following hypothesis applies:

Hypothesis 3: The lower the confidence an individual has in the future personal security, the more likely an individual will express an intention to emigrate.

\section{Quality of Governance (Representation and Corruption)}

Researchers of emigration have identified various "quality of governance" or, more precisely, representation and corruption factors that might be important to the individual's decision to emigrate. These include the extent to which the society awards promotion based on merit, and freedoms to speak and worship freely.

These issues are seen in various parts of the world, particularly among developing nations, where the quality of governance might be found to correlate with other non-economic and economic 
factors. The factors are shown to affect professional-class workers, such as health workers (Sakpkota, Van Teijlingen and Simkhada, 2014), as well as the general population in societies like Greece (Labrianidis, 2014), the Western Balkans (Malaj and de Rubertis, 2017), and in nations around the world from similar governing institutional developments (Cooray and Schneider, 2015; Nejad and Young 2016). In this category, the following hypothesis applies:

Hypothesis 4: The lower the perception of the quality of society, the more likely an individual will express and intention to emigrate.

\section{Quality of Civic Life (Freedom and Tolerance)}

Opportunities to participate meaningfully in community life and in potentially shaping governance processes have not specifically been identified as push factors leading to emigration. However, related literature on policy responses to emigration strongly indicates the importance of citizen participation to develop a favourable response to the situation. Within the context of these policy responses, Hospers (2014) framed the policy responses within four categories: trivializing population shrinkage, countering shrinkage, accepting shrinkage, and utilizing shrinkage. The first is a policy of doing nothing, which is not a sustainable orientation to maintain as it essentially assumes either the population declines will stop and/or reverse and that there will be no or limited economic or social repercussions to a declining population. The second includes potentially aggressive moves to promote growth and stem the tide of emigration; this includes "policy measures aimed at fostering urban growth, including building new residential area and landmarks as well as place marketing" (p. 1512). The third, accepting shrinkage, aims to improve the lives of those who remain and identify the quality of life opportunities in lower-density environments, as well as to make use of such places for social entrepreneurship and innovation that might be relevant for other communities. The final option has been described as "planning for quality instead of quantity" (Haartsen and Venhorst, 2009, p. 225). This means the goal of public policy is not to reach a population target but to enhance overall well-being within a geographic space irrespective of population dynamics.

Identifying which response is appropriate, scholars have argued, requires understanding the interest and values of those who have remained, in addition to the interests and values of those who have left (Haartsen and Venhorst, 2009). This has led to calls for civic engagement in areas that are experiencing shrinkage through voluntary emigration (Guimaraes et al., 2016; Hospers, 2014). With a civic engagement strategy at the core of a community's response, government, and nonprofit leaders can learn about the values and cultures that are of highest priority to maintain in a community while also identifying the strains that are pushing people out. The strategy can further enlist citizens as active participants in producing desired qualities of life, particularly with the potential removal of a more active government presence, given shrinking revenues, or what Hospers (2014) calls an "activating government" (p. 1518) without bias and corruption or perceptions of corruption.

Given the potential significance of civic engagement and an open civic environment to respond to emigration, we can suggest the absence of engagement opportunities and an open civic environment can push people out of a non-supportive environment. In this category, the following hypothesis applies:

Hypothesis 5: The lower the perception of the quality of civic life, the more likely an individual will express an intention to emigrate.

\section{Methodology}

Based on the systematic review of emigration literature, a survey instrument was developed inclusive of the multitude of push, pull, and counter push/pull factors. The survey was administered in June 2019, with a total final response pool of 1030 individuals. Initially, 3159 addresses using multistage stratified cluster sampling were selected from Official Address Register. In the first stage, 
the population was stratified into three strata by the size of locality (above $40000,5000-40000$ and below 5000 inhabitants), depending on the strata the clusters were randomly selected subdistricts ('seniūnija') or households. In the second stage, either households or a person in the household were selected depending on strata. Additional geographical stratification by the county was employed in some of the primary strata. One person older than 18 years old per address was selected for the faceto-face interview. The final sample is 1030 respondents. Due to the complexity of the sampling design and the absence of sampling variables in the dataset, only a simplified version of survey design can be reconstructed. In the following analysis, the impact of survey design was not considered. In logistic regression, the weights were not explicitly introduced. Instead, we employed the approach of including variables relevant to sampling design and poststratification as controls. The sample proportions of gender, age and population per county were very close population proportions. When we applied iterative proportional fitting (raking) procedure for poststratification weights, this had very little influence on univariate results as the proportion of ones in the dependent variable changed by $0.57 \%$ from $20.48 \%$ to $19.91 \%$.

\section{Measures}

We constructed the dependent variable by creating dummy variable where 1 indicates answers "Had been thinking about emigration before and thinking now" and "Never thought about emigration before, but thinking now" and 0 - all the rest answers ("Never considered it", "Was considering before, but not now", "Don't know" and "No answer" ). We justify this categorization as a step towards predicting the explicitly indicated intent of emigration compared to all other categories. There were $20.48 \%$ of total 1030 cases of those who currently consider emigration.

We conducted exploratory factor analysis (EFA) using principal component analysis and principal axis factoring to obtain naturally occurring groups of variables based on eigenvalue above 1 rule. EFA approach is justified in the case of absence of established scales. Before EFA Likert type items were opposite recoded and "Don't knows" recoded into the middle category. The obtained factors had precise meanings related to different spheres of state functioning. Based on EFA, we conducted confirmatory factor analysis (CFA) in covariance-based structural equation modelling approach (CB-SEM), which let us identify candidate items for removal to obtain good psychometric characteristics of resulting scales. Items with low factor loadings were removed from the analysis. In the end, good fit indices were obtained (RMSEA=0.051, SRMR=0.045, CFI=0.92, TLI=0.91; however, the ratio of chi-square test statistics to degrees of freedom is to 3.75). CFA with missing values $(n=28)$ in original dependent variable excluded resulted in a similar magnitude of fit (RMSEA $=0.053, \mathrm{SRMR}=0.047, \mathrm{CFI}=0.926, \mathrm{TLI}=0.914$, the ratio of chi-square test statistics to degrees of freedom is 3.86). Discriminant validity of the latent variables was established via paired constructs test (Anderson, Gerbing 1988). We found that items 'Satisfied with the opportunity to influence public decisions' and 'Satisfied with the opportunities for civic action' belong to different factors. We argue that this due to the underlying nature of factors: 'opportunity to influence public decisions' belongs to a factor encompassing system level, collective features of civic life, while 'opportunities for civic action' belong to a factor that emphasizes proactive features of liberal democracy at the individual level.

The final version of the constructs is presented in Table 1. The construct of Quality of Services in Hypothesis 1 is empirically not unidimensional and forms separate factors of Perceived Quality of Education, Perceived Quality of Health and Social Services, Perceived Quality of Cultural Services and Perceived Quality of Safety and Security Services. These subscales of a more general Quality of Services construct will be used in the subsequent analysis. Other empirical constructs - Perceived Quality of Working Life (Hypothesis 2), Confidence in Future Personal Security (Hypothesis 3), Perceived Quality of Society (Hypothesis 4) and Perceived Quality of Civic Life (Hypothesis 5) - are represented by a single latent variable.

For further analysis outside CB-SEM framework, we constructed scales by simple averaging the items for each scale. 
Table 1. Constructs and their indicators used in the analysis

\begin{tabular}{|c|c|c|c|c|}
\hline Construct & $I D$ & Label & $\begin{array}{l}\text { Factor loading } \\
(E F A)\end{array}$ & $\begin{array}{l}\text { Factor loading } \\
\text { (CFA) }\end{array}$ \\
\hline \multirow{4}{*}{$\begin{array}{l}\text { Confidence in } \\
\text { Future Personal } \\
\text { Security } \\
\end{array}$} & P6.2 & Feel secure in case of illness & .865 & 0.839 \\
\hline & P6.4 & $\begin{array}{l}\text { Feel secure in case of long term } \\
\text { physical or mental illness }\end{array}$ & .848 & 0.774 \\
\hline & P6.1 & Feel secure in retirement & .832 & 1 \\
\hline & P6.3 & Feel secure in case of losing a job & .812 & 0.71 \\
\hline \multirow[t]{4}{*}{$\begin{array}{l}\text { Perceived Quality } \\
\text { of Civic Life }\end{array}$} & P5.23 & $\begin{array}{l}\text { Satisfied with the corruption level of } \\
\text { public service provision } \\
\text { organizations }\end{array}$ & .878 & 1 \\
\hline & P5.22 & $\begin{array}{l}\text { Satisfied with the corruption level } \\
\text { among officers and politicians at the } \\
\text { national and local level }\end{array}$ & .848 & 0.637 \\
\hline & P5.24 & $\begin{array}{l}\text { Satisfied with the opportunity to } \\
\text { influence public decisions }\end{array}$ & .806 & 0.635 \\
\hline & P5.17 & $\begin{array}{l}\text { Satisfied with the representation of } \\
\text { citizens in government institutions }\end{array}$ & .685 & 0.748 \\
\hline \multirow[t]{6}{*}{$\begin{array}{l}\text { Perceived Quality } \\
\text { of Education }\end{array}$} & P5.3 & $\begin{array}{l}\text { Satisfied with the elementary } \\
\text { education system }\end{array}$ & 0.867 & 0.823 \\
\hline & P5.4 & $\begin{array}{l}\text { Satisfied with the general and high } \\
\text { school education system }\end{array}$ & 0.849 & 0.84 \\
\hline & P5.5 & $\begin{array}{l}\text { Satisfied with the vocational training } \\
\text { system }\end{array}$ & 0.817 & 0.767 \\
\hline & P5.2 & $\begin{array}{l}\text { Satisfied with the pre-school } \\
\text { education system }\end{array}$ & 0.813 & 1 \\
\hline & P5.6 & $\begin{array}{l}\text { Satisfied with the higher education } \\
\text { system }\end{array}$ & 0.753 & 0.702 \\
\hline & P5.7 & $\begin{array}{l}\text { Satisfied with the opportunities for } \\
\text { informal and life-long education }\end{array}$ & 0.702 & 0.623 \\
\hline \multirow[t]{5}{*}{$\begin{array}{l}\text { Perceived Quality } \\
\text { of Working Life }\end{array}$} & P3.5 & $\begin{array}{l}\text { Satisfied with the opportunities to } \\
\text { raise qualification }\end{array}$ & .859 & 0.772 \\
\hline & P3.3 & $\begin{array}{l}\text { Satisfied with the organizational } \\
\text { climate }\end{array}$ & .829 & 0.801 \\
\hline & P3.4 & Satisfied with the work conditions & .822 & 0.796 \\
\hline & P3.6 & $\begin{array}{l}\text { Satisfied with the evaluation of } \\
\text { efforts at work }\end{array}$ & .822 & 0.777 \\
\hline & P3.2 & $\begin{array}{l}\text { Satisfied with the career } \\
\text { opportunities }\end{array}$ & .811 & 1 \\
\hline \multirow[t]{3}{*}{$\begin{array}{l}\text { Perceived Quality } \\
\text { of Society }\end{array}$} & P5.18 & $\begin{array}{l}\text { Satisfied with the opportunities for } \\
\text { civic action }\end{array}$ & .820 & 0.76 \\
\hline & P5.19 & Satisfied with the tolerance of people & .817 & 0.713 \\
\hline & P5.20 & $\begin{array}{l}\text { Satisfied with the freedom to express } \\
\text { personal political views }\end{array}$ & .803 & 1 \\
\hline \multirow[t]{3}{*}{$\begin{array}{l}\text { Perceived Quality } \\
\text { of Health and } \\
\text { Social Services } \\
\end{array}$} & P5.15 & $\begin{array}{l}\text { Satisfied with the social security and } \\
\text { support system }\end{array}$ & .866 & 0.8 \\
\hline & P5.16 & Satisfied with the system of taxes & .836 & 1 \\
\hline & P5.1 & Satisfied with the healthcare system & .681 & 0.548 \\
\hline
\end{tabular}




\begin{tabular}{|l|l|l|l|l|}
\hline Construct & ID & Label & $\begin{array}{l}\text { Factor loading } \\
\text { (EFA) }\end{array}$ & $\begin{array}{l}\text { Factor loading } \\
\text { (CFA) }\end{array}$ \\
\hline $\begin{array}{l}\text { Perceived Quality } \\
\text { of Cultural } \\
\text { Services }\end{array}$ & P5.9 & $\begin{array}{l}\text { Satisfied with the opportunities for } \\
\text { cultural activities }\end{array}$ & .879 & 1 \\
\hline & P5.10 & Satisfied with sporting activities & .863 & 0.54 \\
\hline & P5.14 & $\begin{array}{l}\text { Satisfied with the public spaces and } \\
\text { infrastructure }\end{array}$ & .656 & 0.641 \\
\hline $\begin{array}{l}\text { Perceived quality } \\
\text { of Safety and } \\
\text { Security Services }\end{array}$ & P5.12 & $\begin{array}{l}\text { Satisfied with the security from } \\
\text { outside enemies }\end{array}$ & .863 & 0.594 \\
\hline & P5.11 & $\begin{array}{l}\text { Satisfied with the crime control and } \\
\text { prevention }\end{array}$ & .863 & 1 \\
\hline
\end{tabular}

\section{Findings}

The highest differences between groups in Intention to Emigrate are in terms of averages of Perceived Quality of Working Life and Confidence in Future Personal Security: the more satisfied are less inclined to emigrate. Perceived Quality of Governance, Perceived Quality of Civic Life and Perceived Quality of Education differ too, but to a smaller extent. Averages and sums of ranks of Perceived Quality of Health and Social Services, Perceived Quality of Cultural Services Culture, Perceived quality of Safety and Security Services scales are the same for both groups.

Table 2. Means of performance evaluation variables in the categories of Intention to Emigrate and p- values for Mann Whitney U test

\begin{tabular}{|l|c|l|l|l|}
\hline \multicolumn{1}{|c|}{ Variable } & $\mathrm{p}$ & $\begin{array}{c}\text { 0 Does not consider } \\
\text { emigration }\end{array}$ & $\begin{array}{c}\text { 1 Currently considers } \\
\text { emigration }\end{array}$ & \multicolumn{1}{|c|}{ Total } \\
\hline Perceived Quality of Education & $*$ & $3.27(0.62)$ & \multicolumn{1}{|c|}{$\begin{array}{c}\text { Mean (Std. Dev.), } \\
\text { N=211 }\end{array}$} & $\begin{array}{c}\text { Mean (Std. Dev.), } \\
\text { N=1030 }\end{array}$ \\
\hline $\begin{array}{l}\text { Perceived Quality of Working } \\
\text { Life }\end{array}$ & $* * *$ & $3.43(0.86)$ & $3.15(0.71)$ & $3.25(0.64)$ \\
\hline $\begin{array}{l}\text { Confidence in Future Personal } \\
\text { Security }\end{array}$ & $* * *$ & $2.33(0.84)$ & $2.09(0.9)$ & $2.35(0.89)$ \\
\hline Quality of Civic Life & $* *$ & $2.71(0.75)$ & $2.53(0.81)$ & $2.67(0.77)$ \\
\hline $\begin{array}{l}\text { Perceived Perceived Quality of } \\
\text { Governance }\end{array}$ & $*$ & $3.28(0.72)$ & $3.13(0.76)$ & $3.25(0.73)$ \\
\hline $\begin{array}{l}\text { Perceived Quality of Health and } \\
\text { Social Services }\end{array}$ & $\mathrm{ns}$ & $2.89(0.86)$ & $2.82(0.93)$ & $2.87(0.87)$ \\
\hline $\begin{array}{l}\text { Perceived Quality of Cultural } \\
\text { Services }\end{array}$ & $\mathrm{ns}$ & $3.7(0.7)$ & $3.67(0.74)$ & $3.69(0.7)$ \\
\hline $\begin{array}{l}\text { Perceived quality of Safety and } \\
\text { Security Services }\end{array}$ & $\mathrm{ns}$ & $3.24(0.79)$ & $3.16(0.89)$ & $3.22(0.81)$ \\
\hline
\end{tabular}

By looking at the categories with the highest percentage (the mode) of emigration intent, the picture is as follows: emigration is considered more by males, low subjective status holders, students and unemployed, never worked, separate (but not divorced) and never married, having partner (but different households), having children, non-Catholic, once per year or never attending church, earning above 800 Eur/month, living in moderate sized localities (towns), younger people (18 - 29 and 30 - 39 years old). 
Table 3. Intention to Emigrate proportions in categories of qualitative and binned variables

\begin{tabular}{|c|c|c|c|}
\hline Variable & Category & $\begin{array}{l}\text { Currently consider } \\
\text { emigration }\end{array}$ & Total N \\
\hline \multirow[t]{2}{*}{ Gender } & 1 Male & $25.30 \%$ & 455 \\
\hline & 2 Female & $16.70 \%$ & 575 \\
\hline \multirow[t]{3}{*}{ Subjective social status } & 1.00 Low subjective status & $25.30 \%$ & 225 \\
\hline & 2.00 Average subjective status & $18.90 \%$ & 509 \\
\hline & 3.00 High subjective status & $19.60 \%$ & 296 \\
\hline \multirow[t]{7}{*}{ Occupation } & 1 Employed & $23.60 \%$ & 618 \\
\hline & 2 Unemployed & $34.30 \%$ & 67 \\
\hline & 3 Student & $51.60 \%$ & 31 \\
\hline & 5 Disabled & $12.90 \%$ & 31 \\
\hline & 6 Retired & $4.70 \%$ & 234 \\
\hline & 7 Housekeeper & $21.10 \%$ & 38 \\
\hline & 9 Other & $30.00 \%$ & 10 \\
\hline \multirow[t]{6}{*}{ Employment type } & 1 Hired employer & $18.40 \%$ & 862 \\
\hline & $\begin{array}{l}2 \text { Self-employed, without } \\
\text { subordinates }\end{array}$ & $34.00 \%$ & 50 \\
\hline & 3 Self-employed employee & $28.00 \%$ & 25 \\
\hline & 4 Family business & $25.00 \%$ & 16 \\
\hline & 5 Never worked & $42.40 \%$ & 33 \\
\hline & 9 No answer & $22.70 \%$ & 44 \\
\hline \multirow[t]{4}{*}{ Employer type } & 1 For profit organization & $22.20 \%$ & 693 \\
\hline & 2 Non-profit organization & $11.70 \%$ & 222 \\
\hline & 3 Never worked & $42.40 \%$ & 33 \\
\hline & 8 Don't know & $20.70 \%$ & 82 \\
\hline \multirow[t]{6}{*}{ Marital status } & 1 Married & $17.40 \%$ & 556 \\
\hline & 2 Separate, not divorced & $36.40 \%$ & 22 \\
\hline & 3 Officially divorced & $20.80 \%$ & 159 \\
\hline & 4 Widow/er & $6.10 \%$ & 99 \\
\hline & 5 Never married & $34.50 \%$ & 174 \\
\hline & 7 Refuse to answer & $35.00 \%$ & 20 \\
\hline \multirow[t]{5}{*}{ Partner status } & 1 Has partner, same household & $17.50 \%$ & 604 \\
\hline & 2 Has partner, different household & $28.20 \%$ & 71 \\
\hline & 3 No partner & $22.60 \%$ & 310 \\
\hline & 7 Refuse to answer & $25.00 \%$ & 32 \\
\hline & 9 No answer & $53.80 \%$ & 13 \\
\hline \multirow[t]{2}{*}{ Has children } & 1 Yes & $25.50 \%$ & 286 \\
\hline & $2 \mathrm{No}$ & $18.50 \%$ & 744 \\
\hline \multirow[t]{2}{*}{ Catholic } & $0 \mathrm{No}$ & $32.20 \%$ & 143 \\
\hline & 1 Yes & $18.60 \%$ & 887 \\
\hline \multirow[t]{5}{*}{$\begin{array}{l}\text { Religiosity (frequency of attending religious } \\
\text { events) }\end{array}$} & 0 Refused to answer & $18.80 \%$ & 16 \\
\hline & 2 Once a week & $17.90 \%$ & 67 \\
\hline & 32 or 3 times per month & $13.10 \%$ & 61 \\
\hline & 4 Once per month & $16.20 \%$ & 99 \\
\hline & 5 Few times per year & $19.30 \%$ & 383 \\
\hline
\end{tabular}




\begin{tabular}{|c|c|c|c|}
\hline Variable & Category & $\begin{array}{l}\text { Currently consider } \\
\text { emigration }\end{array}$ & Total N \\
\hline & 6 Once per year & $25.40 \%$ & 114 \\
\hline & 7 Less than once per year & $21.10 \%$ & 175 \\
\hline & 8 Never & $27.80 \%$ & 115 \\
\hline \multirow[t]{2}{*}{ Lithuanian nationality } & 0 No & $19.70 \%$ & 137 \\
\hline & 1 Yes & $20.60 \%$ & 893 \\
\hline \multirow[t]{7}{*}{ Personal monthly income (binned) } & $1<=300 \mathrm{Eu}$ & $22.00 \%$ & 182 \\
\hline & $2301-410 \mathrm{Eu}$ & $14.80 \%$ & 108 \\
\hline & $3411-600 \mathrm{Eu}$ & $21.10 \%$ & 147 \\
\hline & $4601-800 \mathrm{Eu}$ & $21.70 \%$ & 129 \\
\hline & $5>800 \mathrm{Eu}$ & $31.90 \%$ & 91 \\
\hline & 999997 Refused to indicate & $18.50 \%$ & 352 \\
\hline & 999998 Doesn't know & $9.50 \%$ & 21 \\
\hline \multirow[t]{4}{*}{ Left-right political self-identification } & $1.00 \mathrm{Left}$ & $21.10 \%$ & 294 \\
\hline & 2.00 Center & $21.40 \%$ & 224 \\
\hline & 3.00 Right & $18.50 \%$ & 195 \\
\hline & 98 Doesn't know & $20.50 \%$ & 317 \\
\hline \multirow[t]{3}{*}{ Locality type } & 1 City & $19.20 \%$ & 360 \\
\hline & 3 Town & $23.60 \%$ & 343 \\
\hline & 4 Rural & $18.70 \%$ & 327 \\
\hline \multirow[t]{5}{*}{ Locality size } & 1 Less than 2000 inhabitants & $17.80 \%$ & 337 \\
\hline & $22001-50000$ inhabitants & $25.20 \%$ & 246 \\
\hline & 350 001-100 000 inhabitants & $28.80 \%$ & 52 \\
\hline & $4100001-500000$ inhabitants & $17.30 \%$ & 196 \\
\hline & 5 Vilnius & $20.10 \%$ & 199 \\
\hline \multirow[t]{6}{*}{ Age groups } & $1.18-29 \mathrm{~m}$. & $35.90 \%$ & 142 \\
\hline & $2.30-39 \mathrm{~m}$. & $30.50 \%$ & 167 \\
\hline & $3.40-49 \mathrm{~m}$. & $26.60 \%$ & 177 \\
\hline & 4. $50-59 \mathrm{~m}$. & $19.20 \%$ & 234 \\
\hline & $5.60-69 \mathrm{~m}$. & $6.10 \%$ & 163 \\
\hline & $6.70+\mathrm{m}$ & $4.80 \%$ & 147 \\
\hline Total & $79.50 \%$ & $20.50 \%$ & 1030 \\
\hline
\end{tabular}

\section{Predicting Intention to Emigrate}

For predicting the Intention to Emigrate, we used binary logistic analysis. We found that only Perceived Quality of Working Life and Confidence in Future Personal Security scales were statistically significant $(\mathrm{p}<0.05)$ predictors of emigration intention. Higher scores of both constructs predict lower odds to consider emigration with Perceived Quality of Working Life being better predictor than Confidence in Future Personal Security. Negative B coefficients indicate lower odds (ratio of probabilities) to be in the emigration category than in a non-emigration category, in other words, minus sign means the increased tendency compared to the average in the sample to belong to zero (not considering emigration) category and plus sign indicates a tendency to belong to category one (considers emigration).

Sociodemographic variables were added to control for available non-attitudinal influences. This was done to account for survey design influence on the results as well as to account for the 
influences that are outside our tested model. To overcome the issue of potential collinearity among categorical sociodemographic variables, a forward stepwise selection approach was adopted for these variables, but very similar results were obtained without applying the stepwise technique. Independent of variable selection method these controls did not remove the statistical significant attitudinal predictors Perceived Quality of Working Life and Confidence in Future Personal Security. Therefore, Perceived Quality of Working Life and Confidence in Future Personal Security remain important predictors of emigration intention even after controlling for sociodemographic variables. The analysis was re-run with "don't know" values imputed (instead of recoding them into the Likert scale's middle point) and with a single step and stepwise methods of independent variables selection. The high statistical significance of the Perceived Quality of Working Life and much lower statistical significance of Confidence in Future Personal Security was confirmed.

The results of the sociodemographic controls reveal that gender, employment type, partner status, ethnic majority status and age group are the most important predictors in this block of variables. Self-employed and self-employed owners are more likely to consider emigration than the reference category (hired worker); those that have no partner are (and those, who chose not to answer) have higher odds than living with a partner in the same household (reference category) to emigrate; older groups compared to the youngest have lower odds of considering emigration increasingly. Lithuanian nationality representatives tend to have higher odds $(p<0.1)$ to emigrate than ethnic minorities.

Table 4. Binary logistic B coefficients (dependent variable - Intention to Emigrate)

\begin{tabular}{|c|c|c|c|c|c|c|}
\hline & $B$ & S.E. & Wald & $d f$ & $p$ value & $\operatorname{Exp}(B)$ \\
\hline Female (1) & -0.494 & 0.173 & 8.141 & 1 & 0.004 & 0.61 \\
\hline Employment type & & & 12.487 & 5 & 0.029 & \\
\hline Self-employed (vs. hired worker) & 1.057 & 0.341 & 9.592 & 1 & 0.002 & 2.879 \\
\hline Self-employed owner (vs. hired worker) & 0.894 & 0.511 & 3.063 & 1 & 0.080 & 2.445 \\
\hline Family business (vs. hired worker) & 0.435 & 0.642 & 0.458 & 1 & 0.498 & 1.545 \\
\hline Never worked (vs. hired worker) & 0.111 & 0.415 & 0.071 & 1 & 0.790 & 1.117 \\
\hline No answer (vs. hired worker) & -0.213 & 0.448 & 0.226 & 1 & 0.635 & 0.808 \\
\hline Partner status & & & 22.663 & 4 & 0.000 & \\
\hline $\begin{array}{l}\text { Has partner, but separate households (vs. } \\
\text { partner, single household) }\end{array}$ & 0.302 & 0.312 & 0.935 & 1 & 0.334 & 1.352 \\
\hline Has no partner (vs. partner, single household) & 0.683 & 0.21 & 10.591 & 1 & 0.001 & 1.979 \\
\hline $\begin{array}{l}\text { Refuse to answer (vs. partner, single } \\
\text { household) }\end{array}$ & 0.182 & 0.459 & 0.158 & 1 & 0.691 & 1.2 \\
\hline No answer (vs. partner, single household) & 2.825 & 0.72 & 15.396 & 1 & 0.000 & 16.867 \\
\hline Lithuanian nationality (1) & 0.497 & 0.255 & 3.812 & 1 & 0.051 & 1.644 \\
\hline Age group & & & 66.144 & 5 & 0.000 & \\
\hline Age group 30-39 (vs. 18-29) & -0.099 & 0.277 & 0.127 & 1 & 0.722 & 0.906 \\
\hline Age group 40-49 (vs. 18-29) & -0.486 & 0.279 & 3.039 & 1 & 0.081 & 0.615 \\
\hline Age group 50-59 (vs. 18-29) & -1.04 & 0.279 & 13.855 & 1 & 0.000 & 0.354 \\
\hline Age group 60-69 (vs. 18-29) & -2.31 & 0.402 & 33.101 & 1 & 0.000 & 0.099 \\
\hline Age group >=70 (vs. 18-29) & -2.6 & 0.461 & 31.779 & 1 & 0.000 & 0.074 \\
\hline Perceived Quality of Working Life & -0.533 & 0.105 & 25.687 & 1 & 0.000 & 0.587 \\
\hline Confidence in Future Personal Security & -0.233 & 0.109 & 4.58 & 1 & 0.032 & 0.792 \\
\hline Constant & 1.13 & 0.495 & 5.22 & 1 & 0.022 & 3.097 \\
\hline
\end{tabular}




\section{Discussion and Conclusions}

Limited and poor economic or financial opportunities in one's home country are usually considered to be the most significant push factors that lead individuals to emigrate. Previous research substantiates this, some of which is discussed in the previous pages. Addressing concerns like low salary and cost of living relative to salary, as well as economic mobility opportunities, are potentially a multi-generation undertaking. Attracting foreign investment to build new industries, employ workers at higher wages, and permit a more comfortable material lifestyle are potentially important policy objectives, but they take time.

Looking instead at non-economic factors can potentially reveal other factors that might push people out, thus opening the opportunity for national and municipal governments, in coordination with the nongovernmental sector, to develop new projects and initiatives that might persuade citizens to remain or to return if they left. Within the control of governments for possible policy, intervention is push factors as well as counter push/pull factors that might, despite the factors that drive citizens away might compel them to remain.

In this article, we examined only the push factors. Future research should consider pull and counter push/pull factors and how they might reduce an individual's inclination to leave or stay in their home country.

Of the categories of push factors, most proved to not be significant in decisions to emigrate. These include quality of services (multiple sub-categories), quality of civic life (freedom and tolerance), and quality of governance (representation and corruption). The categories that are significant are the quality of working life and confidence in future personal security.

These findings are supportive of the notion that context matters when considering drivers of emigration. Much of the literature included in the review found in previous pages originated in multiple countries from throughout the world. Those factors that were found to be significant in each context were unique to and for that place and time. In this time in Lithuania, quality of service, quality of civic life, and quality of governance, though of concern to citizens of Lithuania, are not powerful forces pushing people out of the country. Future research will determine if individual civic integration in the community might act as a counterforce to quality of working life and confidence in the future; as such, civics, as an idea, is not necessarily unimportant. Future research will reveal the importance of civic engagement and integration.

That perceived low quality of working life and low confidence in the future are each likely to lead to an intention to emigrate is important for practical considerations and possible policy interventions. In a generalized way, quality of working life concerns one's satisfaction with their career and opportunity to train and grow into a different or expanded career with more responsibility. This is not an economic concern, as such, but a potential psychological concern of being properly motivated and appreciated at work and a concern of potentially being trapped in a workplace that is not emotionally supportive. Future research can unpack these items further on an individual level, as well as organizational climate assessments across sectors where there are lower perceptions of worklife quality.

From a policy or project intervention perspective, there might be some opportunities for governments to assist the situation. For example, the government can sponsor more and more diverse worker training programs, allowing increased mobility across sectors and organizations. They might also sponsor business incubators for the development of innovative practices related to human resource management. The incubator idea is typically used to help entrepreneurs develop new businesses and business models; it might also fruitfully be used to facilitate the development of innovative business practices that can enhance organizational climate and worker motivation.

The lack of confidence in the future as a push factor has some possible link to economic concerns. If a tragedy strikes, an individual might not have the financial resources to maintain even a basic quality of life. Lithuanian citizens who are not secure in their retirement due to limited pensions, in case of illness, long-term illness, or unemployment are more likely to potentially seek emigration opportunities. Increasing salaries might relieve some of these concerns for individuals, but security 
might take other forms besides financial. Money, after all, is the tool to ensure safe housing, nutritious food, reliable transportation, and so on. Governmental and non-governmental organizations might develop initiatives that ensure a basic quality of life is supported, either through direct cash benefits or community-based civic and volunteer programs that support those who are otherwise impeded in their ability to care for themselves. These and other possible initiatives can be explored further.

Last, additional research on certain demographics, particularly youth, is critical in discussions of Lithuanian emigration. The dialogue in the case of youth who are likely to emigrate might not be to prevent emigration, as global experience can, in the long-term, facilitate foreign investment in new industries and inspire workplace and civic innovations. Instead, the dialogue with respect to youth might be about return migration. This is a different question that requires a separate analysis of available data and beyond.

\section{References}

1. Ailenei, D. Badea, L. Dima, C. The economic effects of emigration of young highly educated Romanians. The USV Annals of Economics and Public Administration, 2015, 15(1), p. 21.

2. Al-Khalisi, N. The Iraqi medical brain drain: A cross-sectional study. International Journal of Health Services, 2013, 43(2), p. 363-378.

3. Anderson, J.C., Gerbing, D.W. Structural equation modeling in practice: A review and recommended two-step approach. Psychological Bulletin, 1988, 103(3), p. 411-423.

4. Azderski, J., Popovska, D. Causes and consequences of migration and deagrarization in rural areas in the Republic of Macedonia. Agriculture and Forestry, 2015, 614(4), p. 263-269.

5. Bernosky de Flores, C. H. A conceptual framework for the study of social capital in new destination immigrant communities. Journal of Transcultural Nursing, 2010, 21(3), p. 205211.

6. Castaldo, A., Deshingkar, P., McKay, A. Internal migration, remittances and poverty: evidence from Ghana and India. Migrating out of poverty working paper. Falmer: University of Sussex. 2012.

7. Castles, S. The forces driving global migration. Journal of Intercultural Studies, 2013, 34(2), p. 122-140.

8. Castro-Palaganas, E. Spitzer, D. L, Kabamalan, M.M.M., Sanchez, M.C., Caricativo, R., Runnels, V., Labonté, R., Murphy, G.T., Bourgeault, I.L. An examination of the causes, consequences, and policy responses to the migration of highly trained health personnel from the Philippines: The high cost of living/leaving — a mixed method study. Human Resources for Health, 2017, 15, p. 25.

9. Cerdeira, L, Machado-Taylor, M. D. L., Cabrito, B., Patrocínio, T., Brites, R., Gomes, R., Lopes, J.T., Vaz, H., Peixoto, P., Magalhães, D., Silva, S., Ganga, R. Brain drain and the disenchantment of being a higher education student in Portugal. Journal of Higher Education Policy and Management, 2016, 38(1), p. 68-77.

10. Clarke, N., Crowe, S., Humphries, N., Conroy, Ro, O’Hare, S., Kavanagh, P, Brugha, R. Factors influencing trainee doctor emigration in a high income country: A mixed methods study. Human Resources for Health, 2017, 15, p. 166.

11. Cooray, A., Schneider, F. Does corruption promote emigration? An empirical examination. Journal of Population Economy, 2015, 29, p. 293-310.

12. Deressa, W., Azazh, A. Attitudes of undergraduate medical students of Addis Ababa University towards medical practice and migration, Ethiopia. BMC Medical Education, 2012, 12 , p. 68.

13. Fu, M. A cultural analysis of China's scientific brain drain: The case of Chinese immigrant scientists in Canadian academia. International Migration and Integration, 2014, 15, p. 197215. 
14. Gray, C., Bilsborrow, R. Environmental influences on human migration in rural Ecuador. Demography, 2013, 50(4), p. 1217-1241.

15. Guimaraes, M. H., Nunes, L. C., Barreira, A. P. and Panagopoulos, T. What makes people stay in or leave shrinking cities? An empirical study from Portugal. European Planning Studies, 2016, 24(9), p. 1684-1708.

16. Haartsen, T. and Venhorst, V. Planning for decline: Anticipating on population decline in the Netherlands. Tijdschrift voor economische en sociale geografie, 2009, 101(2), p. 218-227.

17. Haase, A., Bernt, M., Großmann, K., Mykhnenko, V., Rink, D. Varieties of shrinkage in European cities. European Urban and Regional Studies, 2016, 23(1), p. 86-102.

18. Hartt, M. How cities shrink: Complex pathways to population decline. Cities, 2018, 75, p. 3849.

19. Hercog, M., Van de Laar, M. Motivations and constraints of moving abroad for Indian students. International Migration and Integration, 2017, 18, p. 749-770.

20. Hospers, G. Policy responses to urban shrinkage: From growth thinking to civic engagement. European Planning Studies, 2014, 22(7), p. 1507-1523.

21. Ifanti, A. A., Argyriou, A. A., Kalofonou, F. H., Kalofonos, H. P. Physicians' brain drain in Greece: A perspective on the reasons why and how to address it. Health Policy, 2014, 117(2), p. 210-215.

22. Kumpikaite, V., Zickute, I. Emigracijai įtaka darančių veiksnių analizė. Economics and Management, 2012, (17)2, p. 740 - 746.

23. Lassey, A. T., Lassey, P. D. and Boamah, M. Career destinations of University of Ghana medical school graduates of various year groups. Ghana Medical Journal, 2013, 47(2), p. 87.

24. Lados, G. The impact and importance of return migration in East Central Europe. Forum Geographic, 2014, XII(2), p. 132-137.

25. Lee, E., Moon, M. Korean nursing students' intention to migrate abroad. Nurse Education Today, 2013, 33, p. 1517-1522.

26. Liu, Y., Yin, G., Ma, L. J. Local state and administrative urbanization in post-reform China: A case study of Hebi City, Henan Province. Cities, 2012, 29(2), p. 107-117.

27. Macerolla, A. Varga, E. T. Stuhal, W., Gyorfi, O., Kobeleva, X., Sellner, J. International issues: Cross-border mobility of junior neurologists within and to the European Union. Neurology, 2014, 83, p. e128-e131.

28. Malaj, V., de Rubertis, S. Determinants of migration and the gravity model of migration application on Western Balkan emigration flows. Migration Letters, 2017, 14(2), p. 204-220.

29. Nejad, M. N., Young. A. T. Want freedom, will travel: Emigrant self-selection according to institutional quality. European Journal of Political Economy, 2016, 45, p. 71-84.

30. Oyeyemi, A. Y., Oyetemi, A. L., Maduagwu, S. M., Rufai, A. A., Salamatu, U. Professional satisfaction and desire to emigrate among Nigerian physiotherapists. Physiotherapy Canada, 2012, 64(3), p. 225-232.

31. Piguet, E. Linking climate change, environmental degradation, and migration: a methodological overview. Wiley Interdisciplinary Reviews: Climate Change, 2010, 1(4), p. 517-524.

32. Sapkota, T. N., Van Teijlingen, E. and Simkhada, P. P. Nepalese health workers' migration to the United Kingdom: A qualitative study. Health Science Journal, 2014, 8(1), p. 57-74.

33. Sheikh, A., Naqvi, S. H. A., Sheikh, K., Naqvi, S. H. S., Bandukda, M. Y. Physician migration at its roots: A study on the factors contributing towards a career choice abroad among students at a medical school in Pakistan. Globalization and Health, 2012, 8(1), p. 43.

34. Silva, S., Pinho, P. Planning for shrinkage: Paradox or paradigm. European Planning Studies, 2015, 23(1), p. 12-32.

35. Stark, O., Bloom, D. E. The new economics of labor migration. The american Economic review, 1985, 75(2), p. 173-178. 
36. Stark, O., Levhari, D. On migration and risk in LDCs. Economic development and cultural change, 1982, 31(1), p. 191-196.

37. Stolz, Y., Baten, J. Brain drain in the age of mass migration: Does relative inequality explain migrant selectivity? Explorations in Economic History, 2012, 49(2), p. 205-220.

38. Tabor, A. S., Milfont, T. L. Ward, C. International migration decision-making and destination selection among skilled migrants. Journal of Pacific Rim Psychology, 2015, 9(1), p. 28-41.

39. Ubarevičienè, R., Van Ham, M., Burneika, D. Shrinking regions in a shrinking country: The geography of population decline in Lithuania 2001-2011. Urban Studies Research, 2016, p. $1-18$.

40. Walton-Roberts, M., Runnels, V. E. Rajan, S. I. Sood, A. Nair, S. Thomas, P., Packer, C., MacKenzie, A. Murphy, G. T., Labonte, Ro. Bourgeault, I. L. Causes, consequences, and policy responses to the migration of health workers: Key findings from India. Human Resources for Health, 2017, 15, p. 28.

41. Wan, J., Deng, W., Song, X., Liu, Y., Zhang, S., Su, Y., Lu, Y. Spatio-temporal impact of rural livelihood capital on labor migration in Panxi, southwestern mountainous region of China. Chinese geographical science, 2018, 28(1), p. 153-166.

42. Yamomoto, T. S., Sunguya, B. F., Shiao, L. W. S., Amiya, R. M. Saw, Y. M. Jimba M. Migration of health workers in the Pacific Islands: A bottleneck to health development. AsiaPacific Journal of Public Health, 2012, 24(4), p. 697-709.

43. Zubaran, C. The international migration of health care professionals. Australian Psychiatry, 2012, 20(6), p. 512-517.

Thomas Andrew Bryer, Rimantas Rauleckas, Vishnu Muraleedharan, Eglė Butkevičienė, Jolanta Vaičiūnienè, Eglè Vaidelytė \& Ramunè Miežanskienè

\section{Neekonominiai emigracijos veiksniai, stumiantys piliečius iš Lietuvos}

\section{Anotacija}

Pagrindinis straipsnio tikslas yra aptarti neekonominius emigracijos stūmos veiksnius, kurie daro ịtaką gyventojų ketinimams emigruoti iš Lietuvos. Remiantis išsamia literatūros analize, straipsnyje apžvelgiami emigracijos stūmos ir traukos veiksniai bei jų klasifikacija. Ypatingas dèmesys skiriamas galimiems neekonominiams stūmos veiksniams, kurie paskatina Lietuvos gyventojus emigruoti. Atsižvelgiant ị teorijoje išskiriamus emigraciją skatinančius veiksnius ir 2019 $\mathrm{m}$. birželio mėnesi atliktos reprezentatyvios Lietuvos gyventojų apklausos empirinius duomenis, išskiriamos dvi svarbiausios neekonominių veiksnių kategorijos, kurios paskatina emigruoti: darbo aplinkos kokybė ir saugumo jausmas dèl ateities. Tolimesni moksliniai tyrimai apie neekonominius emigracijos stūmos faktorius gali suteikti pridėtinès vertès siekiant gautus tyrimo rezultatus toliau pritaikyti politikos formavimo srityje bei sumažinti gyventojų norą emigruoti ar paskatinti jų reemigraciją. Šis tyrimas vykdomas igyvendinant projektą "Neekonominių veiksnių poveikis Lietuvos gyventojų emigracijai”. Projektas yra finansuojamas Lietuvos mokslų tarybos pagal programą "Mokslininkų, kitų tyrèjų, studentų mokslinès kompetencijos ugdymas per praktinę mokslinę veiklą" (sutarties Nr. 09.3.3-LMT-K-712-01-170).

Thomas Andrew Bryer - politikos mokslų daktaras, profesorius, Kauno technikos universitetas, Lietuva.

email: thomas.bryer@ucf.edu

Rimantas Rauleckas - docentas, Kauno technikos universitetas, Lietuva. email: rimantas.rauleckas@ktu.lt 
Vishnu Muraleedharan - politikos mokslų doktorantas Kauno technikos universitetas, Lietuva. email: vishnuvalayil@gmail.com

Eglè Butkevičiené - profesorè, Kauno technikos universitetas, Lietuva.

email: egle.butkeviciene@ktu.lt

Jolanta Vaičiūnienè - Savivaldybių mokymo centro direktorè, Kauno technikos universitetas, Lietuva.

email: jolanta.vaiciuniene@ktu.lt

Egle Vaidelyte - docente, Kauno technikos universitetas, Lietuva.

email: egle.vaidelyte@ktu.lt

Ramunè Miežanskienè - politikos mokslų doktorantė, lektorè, Kauno technikos universitetas, Lietuva.

email: ramune.miezanskiene@ktu.lt

Thomas Andrew Bryer - PhD in political sciences, visiting professor at the Kaunas University of Technology, Lithuania

email: thomas.bryer@ucf.edu

Rimantas Rauleckas - asoc. professor, the Faculty of Social Sciences, Arts, and Humanities, Kaunas University of Technology, Lithuania.

email: rimantas.rauleckas@ktu.lt

Vishnu Muraleedharan - is a third-year PhD researcher in Political Sciences at the Faculty of Social Sciences, Arts, and Humanities, Kaunas University of Technology, Lithuania email: vishnuvalayil@gmail.com

Eglè Butkevičiene - professor, the Faculty of Social Sciences, Arts, and Humanities, Kaunas University of Technology, Lithuania.

email: egle.butkeviciene@ktu.lt

Jolanta Vaičiūniene - Director of the Municipal Training Centre at Kaunas University of Technology, Lithuania.

email: jolanta.vaiciuniene@ktu.lt

Egle Vaidelyte - assoc. professor, the Faculty of Social Sciences, Arts, and Humanities, Kaunas University of Technology, Lithuania.

email: egle.vaidelyte@ktu.lt

Ramuné Miežanskiené - doctoral candidate in political science, lecturer, the Faculty of Social Sciences, Arts, and Humanities, Kaunas University of Technology, Lithuania.

email: ramune.miezanskiene@ktu.lt 